\title{
Isoenzymes Detect Variation in Populations of Triatoma brasiliensis (Hemiptera: Reduviidae: Triatominae)
}

\section{Jane Costa/ ${ }^{+}$, Maria Goreti Rosa Freitas-Sibajev*, Verônica Marchon-Silva, Marize Quinhones Pires*, Raquel S Pacheco*}

\author{
Coleção Entomológica, Departamento de Entomologia *Laboratório de Sistemática Bioquímica, Departamento \\ de Bioquímica e Biologia Molecular, Instituto Oswaldo Cruz, Av. Brasil 4365, 21045-900 \\ Rio de Janeiro, RJ, Brasil
}

\begin{abstract}
Triatoma brasiliensis is one of the most important vectors of Chagas disease in the semiarid zone of the northeast of Brazil. Intraspecific morphological and behavioural variation has been reported for different populations. Results for four distinct populations using eight isoenzymes are reported here. The literature describes three subspecies: T. brasiliensis brasiliensis Neiva, 1911; T. brasiliensis melanica Neiva \& Lent, 1941 and T. brasiliensis macromelasoma Galvão, 1956. These subspecies differ mainly in their cuticle colour pattern and were regarded as synonyms by Lent and Wygodzinsky (1979). In order to evaluate whether the chromatic pattern is a morphological variation of different melanic forms within $\mathrm{T}$. brasiliensis or due to interspecific variation, field collections were performed in localities where these three subspecies have been described: Caicó (Rio Grande do Norte), the type-locality for T. b. brasiliensis; Petrolina (Pernambuco) for T. b. macromelasoma and Espinosa (Minas Gerais) for T. b. melanica. A fourth distinct chromatic pattern was found in Juazeiro (Bahia). A total of nine loci were studied. Values of Nei's genetic distance $(D)$ were calculated. T. b. brasiliensis and $\mathrm{T}$. b. macromelasoma are the closest populations with a $D=0.295$. T. b. melanica had a $D \geq 0.537$ when compared to the others, a distance in the range of interspecific variation for other triatomine species.
\end{abstract}

Key words: Triatoma brasiliensis - genetic distances - multilocus enzyme electrophoresis

In the semiarid region of northeast Brazil, Triatoma brasiliensis Neiva, 1911 is found colonizing domiciles and is regarded as one of the most important vectors of Chagas disease. Three subspecies of $T$. brasiliensis are reported in the literature: T. brasiliensis brasiliensis Neiva, 1911, T. brasiliensis melanica Neiva \& Lent, 1941 and $T$. brasiliensis macromelasoma Galvão, 1956. Their descriptions are based on the different chromatic patterns of pronotum, hemelytron and legs. A taxonomic key for the different subspecies can be found in Galvão (1956). These subspecies were synonymized by Lent and Wygodzinsky (1979), who simply asserted that "inter-grading forms are frequent". Whether T. brasiliensis consists of different melanic populations or the chromatic patterns observed are due to interspecific variation is unknown.

In order to study this question, isoenzymatic, morphological and behavioural studies have been undertaken: morphological characters of the geni-

Supported by Fundação Nacional de Saúde and CNPq. Presented on the XXXII Congresso da Sociedade Brasileira de Medicina Tropical

${ }^{+}$Corresponding author. Fax: +55-21-590.3545

Received 30 July 1996

Accepted 17 March 1997 tal structures show considerable individual heterogeneity, thus making the differentiation of the chromatic patterns with these structures impossible. However, observations on the homogeneity and stability of colour patterns of colonies reared in laboratory and the allopatry registered during field captures, indicate that $T$. brasiliensis presents distinct geographic populations (Costa et al. 1996c). Studies on the biology, feeding sources and natural infection of the different chromatic variants have been carried out (Costa et al. 1995a, b). The results using multilocus enzyme electrophoresis for comparing these distinct populations of $T$. brasiliensis are reported here.

\section{MATERIALS AND METHODS}

The insects - One hundred and twenty specimens belonging to four chromatic populations of T. brasiliensis were tested: $30 \mathrm{~F} 1$ adults (15 females and 15 males) of each different chromatic patterns were used from colonies initiated with individuals collected from the field. The specimens captured were found in isolated colonies in different ecotopes. The localities where T. brasiliensis specimens were collected, the populations they represent and number of founder individuals are given in Table I. Voucher specimens are deposited in the Entomological Collection of Instituto Oswaldo Cruz-FIOCRUZ, Rio de Janeiro. 


\section{TABLE I}

Place of origin, ecotope and number of colony founder specimens in four populations of Triatoma brasiliensis used for isoenzyme electrophoresis analysis

\begin{tabular}{|c|c|c|c|c|}
\hline Population & Locality & Location & Ecotope & $\begin{array}{c}\text { Number of colony } \\
\text { founders }\end{array}$ \\
\hline brasiliensis & $\begin{array}{l}\text { Caicó, } \\
\text { Rio Grande do Norte }\end{array}$ & $\begin{array}{c}6^{\circ} 27^{\prime}, 30^{\prime \prime} \mathrm{S} \\
37^{\circ} 05,52 ” \mathrm{~W}\end{array}$ & $\begin{array}{l}\text { Peridomicile } \\
\text { Sylvatic }\end{array}$ & $\begin{array}{l}47 \\
73\end{array}$ \\
\hline macromelasoma & $\begin{array}{l}\text { Petrolina, } \\
\text { Pernambuco }\end{array}$ & $\begin{array}{c}9^{\circ} 23^{\prime} 35^{\prime \prime} \mathrm{S} \\
40^{\circ} 30^{\prime} 27^{\prime} \mathrm{W}\end{array}$ & $\begin{array}{l}\text { Peridomicile } \\
\text { Sylvatic }\end{array}$ & $\begin{array}{l}38 \\
23\end{array}$ \\
\hline ssp. & $\begin{array}{l}\text { Juazeiro, } \\
\text { Bahia }\end{array}$ & $\begin{array}{c}9^{\circ} 29^{\prime}, 49^{\prime}, \mathrm{S} \\
40^{\circ} 30^{\prime} 11^{\prime \prime} \mathrm{W}\end{array}$ & $\begin{array}{l}\text { Peridomicile } \\
\text { Sylvatic }\end{array}$ & $\begin{array}{r}27 \\
5\end{array}$ \\
\hline melanica & $\begin{array}{l}\text { Espinosa, } \\
\text { Minas Gerais }\end{array}$ & $\begin{array}{l}14^{\circ} 55^{\prime} 34^{\prime \prime} \mathrm{S} \\
42^{\circ} 49^{\prime} 09^{\prime \prime} \mathrm{W}\end{array}$ & $\begin{array}{l}\text { Peridomicile } \\
\text { Sylvatic }\end{array}$ & - \\
\hline
\end{tabular}

Enzyme electrophoresis - The insects were cut between the prothorax and the mesothorax. Prothorax and head were ground in $200 \mu \mathrm{l}$ of lysis buffer (500mMTris $\mathrm{HCl}, 26 \mathrm{mM}$ EDTA, $10 \mathrm{mM}$ DTT, $10 \mathrm{mM} \varepsilon$-amino-n caproic acid) and $4 \mu \mathrm{l}$ of each homogenate was loaded for each track for gel electrophoresis.

Fifteen enzymatic systems were tested by agarose gel electrophoresis as described by RosaFreitas et al. (1992): HBDH - $\beta$-hydroxybutyrate dehydrogenase (E.C. 1.1.1.30), MDH - Malate dehydrogenase (E.C. 1.1.1.37), ME - Malic enzyme (E.C. 1.1.1.40), IDH - Isocitrate dehydrogenase (E.C. 1.1.1.42), 6PGD - 6-phosphogluconate dehydrogenase (E.C. 1.1.1.43), LEDH - Leucine dehydrogenase (E.C. 1.4.1.9), NP - Purine nucleoside phosphorylase (E.C. 2.4.2.1.), HK - Hexokinase (E.C. 2.7.1.1), PGM - Phosphoglucomutase (E.C. 2.7.5.1), PEP 2 - Aminopeptidase (E.C. 3.4.11), PEP3 - Aminopeptidase (E.C. 3.4.11), PEPD - Proline dipeptidase (E.C. 3.4.13.9), FUM - Fumarase (E.C. 4.2.1.2), ACON - Aconitase (E.C. 4.2.1.3), MPI - Manose-6-phosphate isomerase (E.C. 5.3.1.8). Single bands were interpreted as belonging to homozygotes, while double bands were interpreted as heterozygotes.

In Table II the number 100 is the most common allele displayed by the different enzymes. The other numbers refer to the relative mobility of the other alleles.

Data from the allelic frequency of the homozygotes and heterozygotes were used to calculate Nei's standard genetic distance between populations (Nei 1987), using the Nei software program (R Cibulskis, Liverpool School of Tropical Medicine). The genetic distance matrix produced by this program was transformed into a dendrogram by using the NTSys software package and UPGMA for clustering (Rohlf 1992).

\section{RESULTS}

Eight out of the 15 systems tested gave readable results for four populations of $T$. brasiliensis. The enzymes NP, LEDH, HBDH, showed no activity. Four enzymes, PEP3, PEPD, MPI and 6PGD, produced only weak bands and were discarded from the analysis. Thus the enzymes used were: MDH, ME, IDH, HK, PGM, FUM, PEP2 and ACON (Fig. 1). MDH and PEP2 each showed two loci. PEP2 produced one electromorph as a faint and undefined zone which was not scored. Thus a total of nine loci were considered: $M d h-1, M d h-2$, Me, Idh, Hk, Pgm, Pep2-2, Fum and Acon. Different electromorph mobilities were scored as distinct allelic expressions (Table II).

Allelic polymorphism was observed in all loci, except for Acon, which was monomorphic within and between populations. Fixed allelic expression within $T$. brasiliensis populations was seen for $M d h-2, M e$, and Pep2-2. Different populations could be separated by distinct biochemical profiles: $M e-116$ and Pgm-89 have distinguished T. $b$. melanica from the other populations. High $I d h-108$ allelic frequency characterized $T$. brasiliensis ssp. Mdh-1-83 could separate T. b. brasiliensis. Mdh2-150 grouped T. b. melanica and T. brasiliensis ssp., whereas the $M d h-2-100$ grouped T. $b$. brasiliensis and T. b. macromelasoma. Pep2-2-400 distinguished T. b. brasiliensis and Pep2-2-300 identified the undetermined form.

Males and females showed no difference in their allelic expression.

The proportion of polymorphic loci for the four populations of $T$. brasiliensis was $\mathrm{P}(0.99)=0.361$ (Table II).

Nei's genetic distance (Nei 1987) among the four chromatic populations of T. brasiliensis were calculated (Table III). The distances encountered 
TABLE II

Allelic frequencies at nine enzymes loci in four populations of Triatoma brasiliensis

\begin{tabular}{|c|c|c|c|c|c|}
\hline Enzymes & Alleles & brasiliensis & melanica & macromelasoma & ssp. \\
\hline$M d h-1$ & $\begin{array}{r}100 \\
83 \\
n\end{array}$ & $\begin{array}{l}0.0000 \\
1.0000 \\
60\end{array}$ & $\begin{array}{l}1.0000 \\
0.0000 \\
60\end{array}$ & $\begin{array}{l}1.0000 \\
0.0000 \\
60\end{array}$ & $\begin{array}{l}0.9667 \\
0.0333 \\
60\end{array}$ \\
\hline$M d h-2^{a}$ & $\begin{array}{r}-150 \\
100 \\
n\end{array}$ & $\begin{array}{l}0.0000 \\
1.0000 \\
60\end{array}$ & $\begin{array}{l}1.0000 \\
0.0000 \\
60\end{array}$ & $\begin{array}{l}0.0000 \\
1.0000 \\
60\end{array}$ & $\begin{array}{l}1.0000 \\
0.0000 \\
60\end{array}$ \\
\hline$M e$ & $\begin{array}{r}116 \\
100 \\
n\end{array}$ & $\begin{array}{l}0.000 \\
1.0000 \\
60\end{array}$ & $\begin{array}{l}1.0000 \\
0.0000 \\
60\end{array}$ & $\begin{array}{l}0.000 \\
1.0000 \\
60\end{array}$ & $\begin{array}{l}0.0000 \\
1.0000 \\
60\end{array}$ \\
\hline$I d h$ & $\begin{array}{r}108 \\
100 \\
\mathrm{n}\end{array}$ & $\begin{array}{l}0.1666 \\
0.8333 \\
60\end{array}$ & $\begin{array}{l}0.0333 \\
0.9667 \\
60\end{array}$ & $\begin{array}{l}0.0667 \\
0.9333 \\
60\end{array}$ & $\begin{array}{l}0.8667 \\
0.1333 \\
60\end{array}$ \\
\hline$H k$ & $\begin{array}{r}100 \\
33 \\
n\end{array}$ & $\begin{array}{l}0.2885 \\
0.7115 \\
52\end{array}$ & $\begin{array}{l}1.0000 \\
0.0000 \\
52\end{array}$ & $\begin{array}{l}0.3462 \\
0.6538 \\
52\end{array}$ & $\begin{array}{r}0.5385 \\
0.4615 \\
52\end{array}$ \\
\hline Pgm & $\begin{array}{r}100 \\
89 \\
56 \\
\mathrm{n}\end{array}$ & $\begin{array}{l}1.0000 \\
0.0000 \\
0.0000 \\
60\end{array}$ & $\begin{array}{l}0.0000 \\
0.9667 \\
0.0333 \\
60\end{array}$ & $\begin{array}{l}1.0000 \\
0.0000 \\
0.0000 \\
60\end{array}$ & $\begin{array}{l}1.0000 \\
0.0000 \\
0.0000 \\
60\end{array}$ \\
\hline Pep2-2 ${ }^{a}$ & $\begin{array}{r}300 \\
100 \\
-400 \\
n\end{array}$ & $\begin{array}{l}0.0000 \\
0.0000 \\
1.0000 \\
60\end{array}$ & $\begin{array}{l}0.0000 \\
1.0000 \\
0.0000 \\
60\end{array}$ & $\begin{array}{l}0.0000 \\
1.0000 \\
0.0000 \\
60\end{array}$ & $\begin{array}{l}1.0000 \\
0.0000 \\
0.0000 \\
60\end{array}$ \\
\hline Fum & $\begin{array}{r}100 \\
96 \\
n\end{array}$ & $\begin{array}{l}0.6333 \\
0.3667 \\
60\end{array}$ & $\begin{array}{l}0.6000 \\
0.4000 \\
60\end{array}$ & $\begin{array}{l}0.6000 \\
0.4000 \\
60\end{array}$ & $\begin{array}{l}0.7000 \\
0.3000 \\
60\end{array}$ \\
\hline Acon & $\begin{array}{r}100 \\
\mathrm{n}\end{array}$ & $32^{1.0000}$ & $\begin{array}{l}1.0000 \\
32\end{array}$ & $\begin{array}{l}1.0000 \\
32\end{array}$ & 32 \\
\hline $\mathrm{P}(0.99)$ & & 0.333 & 0.333 & 0.333 & 0.444 \\
\hline
\end{tabular}

Acon was monomorphic in all samples; $\mathrm{n}=$ number of alleles sampled; $a: M d h-2(-150)$ and Pep-2 (-400) displayed a cathodic mobility

for the four chromatic populations of T. brasiliensis ranged from 0.295 to 1.128 . The smallest genetic distance observed was between $T$. $b$. brasiliensis and T. $b$. macromelasoma $(\mathrm{D}=0.295)$. The next $\mathrm{D}=0.418$ was obtained for $T$. $b$. macromelasoma and the undetermined form. A D $=0.537$ separated T. b. melanica and T. b. macromelasoma. The distances obtained for $T$. $b$. brasiliensis and the undetermined chromatic form was 0.599. T. b. melanica and the undetermined chromatic form had a $\mathrm{D}=0.654$. The greatest distance obtained was 1.128 , between $T . b$. brasiliensis and T. $b$. melanica.

\section{DISCUSSION}

It has long been argued whether the different chromatic patterns presented by different populations of $T$. brasiliensis represent intraspecific varia- tion or are due to interspecific isolation. During field collections at type localities, only one chromatic form was found in each site. These colour patterns are maintained in laboratory reared colonies. They have been stable and homogenous for three generations (Costa et al. 1996c). The four $T$. brasiliensis populations have been kept in the laboratory under the same environmental conditions of temperature, feeding sources and feeding intervals. This suggests that these colour variations are not modified by environmental conditions, and are due to genetic factors.

Males and females of $T$. brasiliensis populations showed no isoenzymatic differences, as has been previously observed for $T$. infestans (Dujardin \& Tibayrenc 1985) and three Rhodnius species (Harry et al. 1992). 

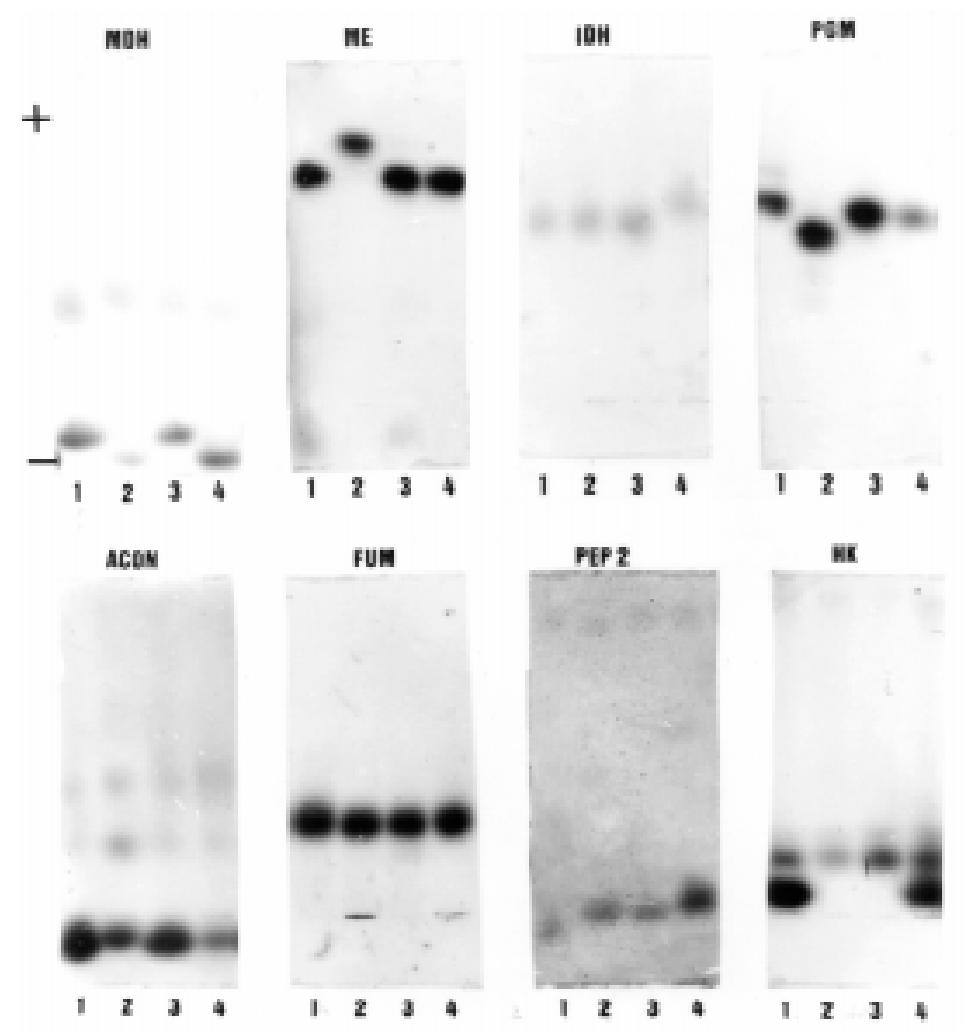

Fig.1: agarose gel eletrophoretic patterns of eight enzymes belonging to four populations of Triatoma brasiliensis. 1: T. b. brasiliensis; 2: T. b. melanica; 3: T. b. macromelasoma; 4: T. brasiliensis $\mathrm{ssp}$.

In this study, the F1 specimens were utilized and during the period in which they were being reared there was no high mortality that could promote a bottle neck effect which could explain the lack of heterozygosity observed. Pasteur et al. (1988) asserted that deviations from HardyWeinberg equilibrium, among other factors, can be caused by sub-structuring in the population of the sample being studied, between which mating is not random (Wahlund effect). The F1 specimens utilized in this study reflect the inbreeding conditions of the isolated colonies forming non-panmitic sub- groups. Comparison among isoenzymatic results of these different chromatic forms showed a high genetic distance, that could be interpreted as an indication of the existence of different well defined taxa (Table III).

Many studies have calculated the genetic distance for well defined taxa such as: T. infestans and T. delpontei $(\mathrm{D}=0.290-0.292$, by Pereira et al. 1996) and for T. infestans and T. sordida $(\mathrm{D}=$ 1.333, by García et al. 1995b). There are also two published comparisons of T. infestans and $T$. platensis: Pereira et al. (1996) analyzed 24 loci,

TABLE III

Nei's genetic distance among four population of Triatoma brasiliensis from Brazil

\begin{tabular}{lcccc}
\hline \multicolumn{1}{c}{ Population } & brasiliensis & macromelasoma & ssp. & melanica \\
\hline brasiliensis & 0.000 & & & \\
macromelasoma & 0.295 & 0.000 & & \\
ssp. & 0.599 & 0.418 & 0.000 & \\
melanica & 1.128 & 0.537 & 0.654 & 0.000 \\
\hline
\end{tabular}


registering $\mathrm{D}=0.094-0.124$ and García et al. (1995b) which analyzed 14 loci, with a $\mathrm{D}=0.45$. These data demonstrate the wide range of genetic distances measurements between species, although biochemical analysis carried out at intraspecific level have shown a low genetic distance. Dujardin et al. (1987) analyzed wild and domestic populations of T. infestans from Cochabamba (Bolívia) concluding they are virtually identical comparing the 19 enzymatic gene loci indicating lack of speciation between these two populations $(\mathrm{D}=0.001$ - 0.004). García et al. (1995a) studied nine colonies of T. infestans established with individuals collected at different localities in South America. They observed uniformity of allele frequencies among populations, explaining the result in terms of the recent and rapid dispersal of the species from the site of origin, Cochabamba Valley in Bolivia $(\mathrm{D}=$ $0.001-0.011$ ).

The present study has allowed us to distinguish the four populations of $T$. brasiliensis demonstrating that they are genetically distinct from one another (Table III). All the genetic distances have situated them at the interspecific level, when compared to the results above mentioned (Fig. 2). T. brasiliensis melanica has a higher genetic distance (>0.537) from the other T. brasiliensis populations. Although specimens of T. $b$. macromelasoma and the $T$. brasiliensis ssp. had been collected in nearby localities (Petrolina and Juazeiro, separated by the San Francisco River) they presented a significant genetic distance $(D=0.418)$.

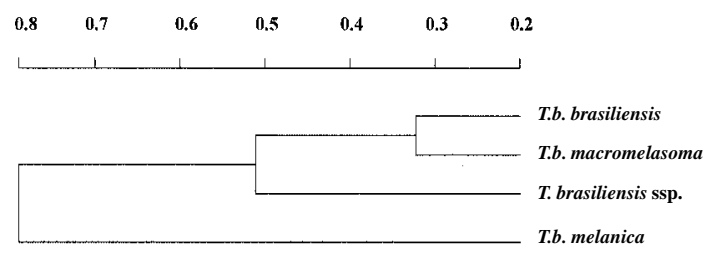

Fig. 2: dendrogram showing the genetic distances among populations of Triatoma brasiliensis.

In order to elucidate the taxonomic status of these different chromatic populations, it would be necessary: define the geographic distribution of each population, analyze the colour patterns and the genitalia (Costa \& Marchon-Silva 1993), morphological studies of eggs using scanning electron microscopy (Costa et al. 1996a), apply other genetic analysis such as chromosome and DNA markers and determine the existence or non existence of reproductive isolation mecanisms via directed crosses (Costa et al. 1996b).
The validation of distinct taxonomic status for these different chromatic patterns will be important for the basic knowledge of this group of insects. This information will improve the understanding of the role of these "distinct melanic forms" in the transmission and possibly in the control of Chagas disease.

\section{ACKNOWLEDGMENTS}

To Drs Hooman Momen and Francisco Panzera for their valuable comments on the manuscript.

\section{REFERENCES}

Costa J, Marchon-Silva V 1993. Morphological studies on the intraspecific variation of Triatoma brasiliensis Neiva, 1911 (Reduviidae-Triatominae). Mem Inst Oswaldo Cruz 88 (Suppl. I): 249.

Costa J, Duarte R, Marchon-Silva V 1995a. Studies in progress on the intra-specific variation of Triatoma brasiliensis Neiva, 1911 (Hemiptera, Reduviidae, Triatominae). I. Feeding habits. Mem Inst Oswaldo Cruz 90 (Suppl. I): 229.

Costa J, Marchon-Silva V, Britto C, Pires MQ, Pacheco RS 1995b. Preliminary studies on the intra-specific variation of Triatoma brasiliensis Neiva, 1911 (Hemiptera, Reduviidae, Triatominae). II. Natural infectivity. Mem Inst Oswaldo Cruz 90 (Suppl. I): 229.

Costa J, Barth OM, Marchon-Silva V, Almeida CE 1996a. Morphological studies on the intraspecific variation of Triatoma brasiliensis Neiva, 1911 (Hemiptera-Reduviidae-Triatominae): scanning electron microscopy and morphometry of eggs. Mem Inst Oswaldo Cruz 91 (Suppl. I): 128.

Costa J, Marchon-Silva V, Almeida JR 1996b. Does hybridization clarify the taxonomic status of different melanic forms of Triatoma brasiliensis Neiva, 1911 (Hemiptera-Reduviidade-Triatominae)? Mem Inst Oswaldo Cruz 91 (Suppl. I): 128.

Costa J, Marchon-Silva V, Freitas-Sibajev MGR, Pires MQ, Pacheco RS 1996c. Estudos isoenzimáticos detectam variação intra-específica em Triatoma brasiliensis Neiva, 1911 (Hemiptera, Reduviidade, Triatominae). Rev Soc Bras Med Trop 29 (Suppl. I): 129.

Dujardin JP, Tibayrenc M 1985. Etude de 11 enzymes et données de génétique formelle pour 19 loci enzymatiques chez Triatoma infestans (Hemiptera, Reduviidade). Ann Soc belge Med Trop 65: 271-280.

Dujardin JP, Tibayrenc M, Venegas E, Maldonado L, Desjeux P, Ayala FJ 1987. Isozyme evidence of lack of speciation between wild and domestic Triatoma infestans (Hemiptera, Reduviidade) in Bolivia. J Med Entomol 24: 40-45.

Galvão AB 1956. Triatoma brasiliensis macromelasoma n. subsp. (Hemiptera, Reduviidae). Rev Bras Mal D Trop 7: 455-457.

García BA, Barata JMS, Blanco A 1995a. Enzyme polymorphism among Triatoma infestans (Hemiptera: Reduviidae) colonies. J Med Entomol 32: 126-133.

García BA, Canale DM, Blanco A 1995b. Genetic structure of four species of Triatoma (Hemiptera: 
Reduviidade) from Argentina. J Med Entomol 32: 134-137.

Harry M, Galindez I, Cariou ML 1992. Enzymatic variability and differentiation between Rhodnius prolixus, $R$. robustus and $R$. pictipes, vectors of Chagas disease in Venezuela. Med Vet Entomol 6: 37-43.

Lent H, Wygodzinsky P 1979. Revision of the Triatominae (Hemiptera, Reduviidae) and their significance as vectors of Chagas'disease. Bull Amer Mus Natur Hist 163: 123-520.

Nei M 1987. Molecular Evolutionary Genetics. Columbia University Press, New York. 512 pp.

Pasteur N, Pasteur G, Bonhomme F, Catalan J, Britton-
Davidian J 1988. Practical Isozyme Genetics. English Ediction Ellis Horwood Limited. 215 pp.

Pereira J, Dujardin JP, Salvatella R, Tibayrenc M 1996. Enzymatic variability and phylogenetic relatedness among Triatoma infestans, T. platensis, T. delpontei and T. rubrovaria. Heredity 77: 47-54.

Rohlf FJ 1992. Numerical Taxonomy and Multivariate Analysis System. Version 1.70. Applied Biostatistic Inc., 3 Heritage Lane, Setanket, New York. 117 pp. Rosa-Freitas MG, Broomfield G, Priestman A, Milligan PJM, Momen H, Molyneux DH 1992. Cuticular hydrocarbons, isoenzymes and behavior of three populations of Anopheles darling from Brazil. J Am Mosq Control Assoc 8: 357-366. 